\title{
CRF and urocortin peptides as modulators of energy balance and feeding behavior during stress
}

\author{
Andreas Stengel ${ }^{1 *}$ and Yvette Taché ${ }^{2 *}$ \\ Division of General Internal and Psychosomatic Medicine, Charité Center for Internal Medicine and Dermatology, Charité-Universitätsmedizin Berlin, Berlin, \\ Germany \\ ${ }^{2}$ CURE: Digestive Diseases Research Center, Center for Neurobiology of Stress and Women's Health, Department of Medicine, Digestive Diseases Division at the \\ University of California Los Angeles, and VA Greater Los Angeles Health Care System, Los Angeles, CA, USA
}

\author{
Edited by: \\ David Lovejoy, University of Toronto, \\ Canada

\section{Reviewed by:} \\ Tamas Kozicz, Radboud University \\ Medical Center, Netherlands \\ Gustavo M. Somoza, Instituto de \\ Investigaciones \\ Biotecnologicas-Instituto \\ Tecnologico de Chascomus, \\ Argentina

\section{*Correspondence:} \\ Andreas Stengel, Division of \\ General Internal and Psychosomatic \\ Medicine, Charité Center for Internal \\ Medicine and Dermatology, \\ Charité-Universitätsmedizin Berlin, \\ Campus Benjamin Franklin, \\ Hindenburgdamm 30, 12200 Berlin, \\ Germany \\ e-mail: andreas.stengel@charite.de; \\ Yvette Taché, Center for \\ Neurobiology of Stress, CURE \\ Building 115, Room 117, VA GLA \\ Healthcare System, 11301 Wilshire \\ Blvd, Los Angeles, CA 90073, USA \\ e-mail: ytache@mednet.ucla.edu
}

Early on, corticotropin-releasing factor (CRF), a hallmark brain peptide mediating many components of the stress response, was shown to affect food intake inducing a robust anorexigenic response when injected into the rodent brain. Subsequently, other members of the CRF signaling family have been identified, namely urocortin (Ucn) 1, Ucn 2, and Ucn 3 which were also shown to decrease food intake upon central or peripheral injection. However, the kinetics of feeding suppression was different with an early decrease following intracerebroventricular injection of CRF and a delayed action of Ucns contrasting with the early onset after systemic injection. CRF and Ucns bind to two distinct G-protein coupled membrane receptors, the $\mathrm{CRF}_{1}$ and $\mathrm{CRF}_{2}$. New pharmacological tools such as highly selective peptide $\mathrm{CRF}_{1}$ or $\mathrm{CRF}_{2}$ agonists or antagonists along with genetic knock-in or knock-out models have allowed delineating the primary role of $\mathrm{CRF}_{2}$ involved in the anorexic response to exogenous administration of CRF and Ucns. Several stressors trigger behavioral changes including suppression of feeding behavior which are mediated by brain CRF receptor activation. The present review will highlight the state-of-knowledge on the effects and mechanisms of action of $\mathrm{CRF} / \mathrm{Ucns}-\mathrm{CRF}_{1 / 2}$ signaling under basal conditions and the role in the alterations of food intake in response to stress.

Keywords: body weight, CRF, food intake, stress, urocortin

\section{INTRODUCTION}

Hans Selye was the first to introduce the biological concept and term of stress based on similar macroscopic changes namely the development of gastric erosions, involution of the lymphatic organs and hypertrophy of the adrenal glands in response to the exposure to a variety of noxious chemical agents or physical constraint in rats (Selye, 1936, 1976). Fourteen years later, Geoffrey Harris showed that various stressors induced the release of adrenocorticotropic hormone (ACTH) and provided the evidence for the release of a hypothalamic factor acting via hypophyseal portal vessels (De Groot and Harris, 1950; Harris, 1950). This concept was further supported by the purification of a hypothalamic factor stimulating ACTH release from the rat pituitary gland in 1955 (Guillemin and Rosenberg, 1955; Saffran et al., 1955). Therefore, this factor-which eluded its identification up to 1981-was named corticotropin-releasing factor (CRF) (Guillemin and Rosenberg, 1955; Saffran et al., 1955). From the beginning and with great foresight, Selye assumed that CRF would be "the first mediator that integrates the adaptive bodily response to stress" (Selye, 1976). After its identification and characterization by Vale's group as a 41 amino acid (aa) peptide (Vale et al., 1981), numerous studies unraveled pleiotropic stress-like actions induced by central injection of CRF beyond the mere activation of the hypothalamus-pituitary-adrenal gland axis. This includes the modulation of autonomic (sympathetic and sacral parasympathetic activation), visceral and immune functions but also behaviors (anxiogenic, reproductive and feeding) (Dunn and Berridge, 1990; De Souza, 1995; Heinrichs et al., 1997; Habib et al., 2000; Bale and Vale, 2004; Stengel and Taché, 2010).

It is well known that acute exposure to various stressors such as visceral (physical) (Stengel et al., 2011), immune (Basa et al., 2003; Wang et al., 2006; Stengel et al., 2010) and cognitive (psychological) (Rybkin et al., 1997; Kinzig et al., 2008; Calvez et al., 2011) stressors results in the suppression of food intake in rodents. This inhibitory effect is largely mediated by the recruitment of CRF signaling pathways in the brain. This is supported by the activation of CRF-containing neurons and pituitary ACTH release (Calvez et al., 2011; Wang et al., 2011a), the mimicry by brain injection of CRF or related peptides, urocortins, and its prevention by central injection of CRF receptor antagonists in rats (Koob and Heinrichs, 1999). Interestingly, models of chronic stress can have a dual effect on feeding and food preference in experimental animals and humans (Dallman, 2010). Social defeat 
stress led to an increase in daily food intake in mice giving rise to the recruitment of other/additional signaling systems under these conditions, while chronic exposure to a battery of physi$\mathrm{cal} /$ environmental stressors reduces food intake and body weight in rats (Lutter et al., 2008; Kumar et al., 2013).

The present review will describe first the state-of-knowledge on the distribution of the CRF signaling systems including CRF receptors, CRF, and urocortins in the brain and in the periphery and the effects and mechanisms of central and peripheral injection of CRF and Ucns on food intake. Lastly, the role of CRF receptor signaling pathways in the modulation of food intake under conditions of stress will be highlighted.

\section{THE CRF SIGNALING SYSTEM LIGANDS: CRF AND UROCORTINS}

CRF was identified in 1981 as a 41 -aa hypothalamic peptide stimulating the release of ACTH and $\beta$-endorphin from the anterior part of the pituitary gland (Vale et al., 1981). Subsequently, other members of the CRF family were identified (Vaughan et al., 1995; Hsu and Hsueh, 2001; Lewis et al., 2001; Reyes et al., 2001), namely Ucn 1, a 40-aa peptide sharing 45\% sequence identity with rat/human (r/h) CRF, Ucn 2, a 39-aa peptide sharing 34\% homology with $\mathrm{r} / \mathrm{h} \mathrm{CRF}$ and $42 \%$ with $\mathrm{r} / \mathrm{h}$ Ucn 1 (Reyes et al., 2001; Vaughan et al., 2013), and Ucn 3, a 38-aa peptide sharing only $26 \%$ homology with $\mathrm{r} / \mathrm{h} \mathrm{CRF}$ and $21 \%$ with $\mathrm{r} / \mathrm{h} \mathrm{Ucn}$ 1 , respectively (Lewis et al., 2001). These four peptides are all derived from distinct genes highly conserved across mammalian, non-mammalian, and invertebrate species consistent with the physiological importance of this signaling system (Lovejoy and de Lannoy, 2013).

CRF is widely distributed in the rodent brain with robust expression at the mRNA and peptide level in the cerebral cortex, amygdala, hippocampus, paraventricular nucleus of the hypothalamus (PVN) and the Barrington's nucleus (Valentino et al., 1994; Wang et al., 2011a; Beckerman et al., 2013). Despite the fact that urocortins show an extensive brain distribution, little neuroanatomical overlap exists between CRF and urocortins. Ucn 1 has limited brain distribution with one major expression site which is the Edinger-Westphal nucleus (EWN) (Bittencourt et al., 1999; Morin et al., 1999; Shah et al., 2013), and to a lesser extent, the olfactory bulb, supraoptic nucleus (SON), ventromedial hypothalamus (VMH), lateral hypothalamic area, lateral superior olive, ambiguus nucleus, dorsolateral tegmental nucleus, linear and dorsal raphe nuclei, substantia nigra and cranial nerve motor nuclei, namely facial and hypoglossal (Kozicz et al., 1998; Bittencourt et al., 1999). Ucn 2 mRNA is found in the parvoand magnocellular part of the PVN, the arcuate nucleus of the hypothalamus, SON, locus coeruleus, in cranial nerve motor nuclei (trigeminal, facial and hypoglossal nuclei) and also in the ventral horn of the spinal cord (Reyes et al., 2001; Mano-Otagiri and Shibasaki, 2004). It is important to note that the knowledge on Ucn 2 's distribution at the peptide level has been limited by the lack of a specific Ucn 2 antibody. Lastly, Ucn 3 mRNA and peptide expression was detected in the amygdala, lateral septum, PVN, VMH, basomedial nucleus of the stria terminalis, dorsal raphe nucleus and in the area postrema (Lewis et al., 2001; Li et al., 2002; Mano-Otagiri and Shibasaki, 2004; Venihaki et al., 2004).
Besides the widespread expression of CRF and related peptides initially found in the central nervous system and thought to be restricted to this site, as commonly observed for other peptides, CRF and urocortins were also detected in visceral organs, namely the lung, heart, spleen, adipose tissue, gonads (Boorse and Denver, 2006; Wypior et al., 2011), pancreas (Li et al., 2003; van der Meulen et al., 2012) and the gastrointestinal tract (Kozicz and Arimura, 2002; Taché and Perdue, 2004; Taché and Bonaz, 2007; Yuan et al., 2012b) including the enteric nervous system (Liu et al., 2006; Kimura et al., 2007). The past decade witnessed an increasing knowledge on the peripheral expression and regulation of CRF and urocortin signaling systems and recognition of their implication in health and disease (Yuan et al., 2010; Buckinx et al., 2011; Overman et al., 2012; Diaz and Smani, 2013; Onorati et al., 2013).

\section{CRF RECEPTORS}

CRF ligands bind to $\mathrm{CRF}_{1}$ and/or $\mathrm{CRF}_{2}$ receptors consisting of 415 aa and 411 aa, respectively, that are encoded from two distinct genes belonging to the B1 subfamily of seven-transmembrane G-protein coupled receptors encompassing seven membranespanning $\alpha$-helices and an extracellular domain (Perrin and Vale, 1999). Both receptors share $70 \%$ identity within their species homologue. The most variable component is the binding domain that encompasses the N-terminal and the three extracellular coils that share only $40 \%$ homology between the two receptor subtypes. In their N-terminal extracellular region, CRF receptors contain several potential points of $\mathrm{N}$-glycosylation along with several Cys residues that form disulfide bonds closely associated with their functionality (Zmijewski and Slominski, 2010; Liapakis et al., 2011). Various partial or total exon deletions or insertions in the CRF gene - in some cases associated with a shift in the open reading frame - generate multiple isoforms of $\mathrm{CRF}_{1}$ and $\mathrm{CRF}_{2}$ receptors (Pisarchik and Slominski, 2001; Wu et al., 2007, 2011; Zmijewski and Slominski, 2010). Among the nine human $\mathrm{CRF}_{1 \mathrm{a}-\mathrm{i}}$ variants, $\mathrm{CRF}_{1}$, also named $\mathrm{CRF}_{1 \mathrm{a}}$, is the main functional receptor. The $\mathrm{CRF}_{1 \mathrm{~b}}$ isoform is also called pro-CRF $\mathrm{C}_{1}$, and this is the only variant coded by all 14 exons, leading to a 29 -aa insertion into the first intracellular loop which impairs agonist binding and signaling activity compared to $\mathrm{CRF}_{1 \mathrm{a}}$ (Markovic and Grammatopoulos, 2010). The other isoforms $\mathrm{CRF}_{1 \mathrm{c}-\mathrm{i}}$ have the exon 6 spliced out and in addition there are either cryptic exons (1h), or the skipping of single (1c, 1d, and 1f) or multiple exons (1e and 1g) (Pisarchik and Slominski, 2001, 2004; Wu et al., 2011). The latest splice variant identified, $\mathrm{CRF}_{1 \mathrm{i}}$ has a deletion of exon 4 and is functional. This was shown by the increased phosphorylation of the extracellular signal regulated kinase $1 / 2(E R K 1 / 2)$ in response to Ucn 1 assessed in $\mathrm{CRF}_{1 \mathrm{i}}$ transfected human embryonic kidney (HEK) cells (Wu et al., 2011). Other soluble isoforms such as $\mathrm{CRF}_{1 \mathrm{e}}$ and $\mathrm{CRF}_{1 \mathrm{~h}}$ may play a modulatory role as their expression in transfected COS cells either decreased or amplified the $\mathrm{CRF}_{1 \alpha}$-coupled cAMP production induced by Ucn 1 (Pisarchik and Slominski, 2004).

With regards to the $\mathrm{CRF}_{2}$, three functional splice variants $2 \mathrm{a}$, $2 \mathrm{~b}$, and $2 \mathrm{c}$ (also originally named $2 \alpha, 2 \beta$, and $2 \gamma$ ) derived from alternative splicing exist in humans, while in other mammals only two isoforms, $\mathrm{CRF}_{2 \mathrm{a}}$ and $\mathrm{CRF}_{2 \mathrm{~b}}$ are expressed (Hauger et al., 
2003; Hillhouse and Grammatopoulos, 2006). These isoforms differ structurally in their N-terminal extracellular domains (Hauger et al., 2003). The 34-aa N-terminal extracellular region of the $\mathrm{CRF}_{2 \mathrm{a}}$ is replaced by 61 aa in the $\mathrm{CRF}_{2 \mathrm{~b}}$ and 20 aa in the $\mathrm{CRF}_{2 \mathrm{c}}$, while the $\mathrm{C}$-terminus is common to all $\mathrm{CRF}_{2}$ receptor splice variants (Miyata et al., 2001; Dautzenberg et al., 2004; Wu et al., 2007). Sequence comparison indicated high homology between rat and mouse $\mathrm{CRF}_{2 \mathrm{a}}$ (94\%) and mouse and human (92\%) (Dautzenberg et al., 2004). The presence of $\mathrm{CRF}_{2 \mathrm{a}}$ in amphibian species suggests an earliest occurrence of this splice variant during vertebrate evolution, while the $\mathrm{CRF}_{2 \mathrm{~b}}$ is less conserved and appears to be evolutionarily younger and is found only in mammals (Dautzenberg et al., 2001). Recently, Chen et al. reported a novel $\mathrm{CRF}_{2 \mathrm{a}}$ splice variant in the mouse brain that includes the first extracellular domain of the $\mathrm{CRF}_{2 \mathrm{a}}$ receptor and acts as a soluble binding protein $\left(\mathrm{sCRF}_{2 \mathrm{a}}\right)$, thereby modulating the accessibility and signaling (Chen et al., 2005). In the rat esophagus, $\mathrm{CRF}_{2 \mathrm{~b}}$ wild-type transcript is predominantly expressed and in addition, several new $\mathrm{CRF}_{2}$ splice variants including six $\mathrm{CRF}_{2 a}$ isoforms were identified (Wu et al., 2007; Yuan et al., 2012b).

Similar to CRF, the $\mathrm{CRF}_{1}$ receptor displays a wide distribution throughout the brain. In rats, the $\mathrm{CRF}_{1}$ is densely and widely expressed in the forebrain, in the septal region and amygdala (Justice et al., 2008), whereas basal expression is low in the hypothalamus but up-regulated under conditions of stress and also by CRF as a feed-forward mechanism (Bonaz and Rivest, 1998; Imaki et al., 2001; Konishi et al., 2003). Contrasting with the wide distribution of the $\mathrm{CRF}_{1}$, expression of the $\mathrm{CRF}_{2}$ is mainly found in the lateral septum, amygdala and hypothalamic nuclei including the SON and VMH, dorsal raphe, area postrema and nucleus tractus solitarius (Bittencourt and Sawchenko, 2000; Chen et al., 2012). Both, $\mathrm{CRF}_{1}$ (laminae III-VIII) and $\mathrm{CRF}_{2}$ mRNA (laminae III-X) were also detected in the mouse spinal cord (Korosi et al., 2007). In the periphery, the $\mathrm{CRF}_{1}$ was detected in the anterior and intermediate lobe of the pituitary gland (Turnbull and Rivier, 1997) and in the gastrointestinal tract more prominently in colonic endocrine, neuronal and immune cells (Chatzaki et al., 2004; Yuan et al., 2007, 2012a), while $\mathrm{CRF}_{2}$ was found in the stomach including the luminal surface of the crypts and in blood vessels of the submucosal layer (Chatzaki et al., 2004; Yuan et al., 2012b).

Following the identification of CRF receptors, the characterization of binding affinities to endogenous ligands showed that the $\mathrm{CRF}_{1}$ and $\mathrm{CRF}_{2}$ receptors display distinct affinities to CRF and urocortins (Lewis et al., 2001; Hauger et al., 2003; Hillhouse and Grammatopoulos, 2006). CRF displays a 10- to 40 -fold higher affinity for the $\mathrm{CRF}_{1}$ than the $\mathrm{CRF}_{2}$ receptor, whereas Ucn 1 binds with equal affinity to both CRF receptors thereby displaying a 100-fold higher affinity to the $\mathrm{CRF}_{2}$ receptor compared to CRF (Grace et al., 2007). It is important to note that so far no endogenous selective ligand for the $\mathrm{CRF}_{1}$ has been identified. In contrast to CRF and Ucn 1, Ucn 2, and Ucn 3 show high selectivity for the $\mathrm{CRF}_{2}$ (Grace et al., 2007). In contrast to the $\mathrm{CRF}_{1}$ receptor isoforms, binding characteristics of the CRF receptor splice variants, $\mathrm{CRF}_{2 \mathrm{a}}, \mathrm{CRF}_{2 \mathrm{~b}}$, and $\mathrm{CRF}_{2 \mathrm{c}}$ are almost identical with high affinity for Ucn 1, Ucn 2, and Ucn 3, and lower affinity for r/hCRF (Kostich et al., 1998; Ardati et al., 1999; Suman-Chauhan et al.,
1999; Lewis et al., 2001). However, the isoforms of $\mathrm{CRF}_{2 \mathrm{a}}$ show distinct pharmacological profiles; the mouse $\mathrm{SCRF}_{2 \mathrm{a}}$ receptor has very low affinity for Ucn 2 and Ucn 3, while binding to Ucn 1 (Ki $6.6 \mathrm{nM})$, and, to a lesser extent, to CRF $(23 \mathrm{nM})$, and inhibits the cAMP and ERK1/2-p42,44 responses to Ucn 1 and CRF (Chen et al., 2005). In contrast, rat $\mathrm{CRF}_{2 a-t r}$ binds with low affinity to CRF (Kd $12.7 \mathrm{nM}$ ) and does not bind to Ucn 1 (Miyata et al., 1999).

\section{FOOD INTAKE INHIBITORY ACTIONS OF BRAIN CRF AND Ucns}

It is well documented that members of the CRF family and more prominently Ucns injected into the brain ventricle suppress food intake in various species (Zorrilla et al., 2003; Wang et al., 2011b) and increase energy expenditure (Richard et al., 2002). In ad libitum fed rats, intracerebroventricular (icv) injection of CRF (Spina et al., 1996), Ucn 1 (Spina et al., 1996; Yakabi et al., 2011), Ucn 2 (Ohata and Shibasaki, 2004), and Ucn 3 (Ohata and Shibasaki, 2004) decreases dark phase food intake. At the lowest icv doses, Ucn 1 and Ucn 2 decrease food intake without inducing conditioned taste aversion or visceral illness (Benoit et al., 2000; Inoue et al., 2003; Zorrilla et al., 2004). It is to note that icv Ucn 1 is more potent in suppressing food intake compared to CRF (Spina et al., 1996), and Ucn 2 is 10-fold more potent than Ucn 3 in reducing food intake (Pelleymounter et al., 2004). Kinetic studies also showed differences in the time course of food intake suppression induced by icv injection of the CRF-related peptides. CRF, a preferential $\mathrm{CRF}_{1}$ agonist, induces a rapid onset and short-term reduction of the re-feeding response to an overnight food deprivation in mice and rats (Ohata and Shibasaki, 2004; Pelleymounter et al., 2004), while the dark phase food intakereducing effect of icv Ucn 2 or Ucn 3 is delayed (onset $>3 \mathrm{~h}$ ) and long lasting in rats (Inoue et al., 2003; Zorrilla et al., 2004). Conversely, in $\mathrm{CRF}_{1}$ deficient mice, icv Ucn 1 still induces a delayed onset suppression of food intake while the early phase is no longer observed (Bradbury et al., 2000). Similar to the acute effects, under chronic conditions observed in mice overexpressing CRF there is also a curtailing of the re-feeding response to a fast (Stengel et al., 2009).

Convergent studies established the primary role of $\mathrm{CRF}_{2}$ in mediating the anorexigenic effect of acute or repeated icv injections of CRF or Ucns using complementary pharmacologic (selective $\mathrm{CRF}_{1}$ or $\mathrm{CRF}_{2}$ antagonists) (Smagin et al., 1998; Contarino et al., 2000; Pelleymounter et al., 2000; Cullen et al., 2001; Sekino et al., 2004) and gene deletion ( $\mathrm{CRF}_{1}$ or $\mathrm{CRF}_{2}$ deficient mice) (Bradbury et al., 2000) approaches in addition to the selective $\mathrm{CRF}_{2}$ agonists, Ucn 2, and Ucn 3 (Cullen et al., 2001; Richard et al., 2002; Zorrilla et al., 2003; Pelleymounter et al., 2004). To date, the role of $\mathrm{CRF}_{1}$ in mediating the effects of icv CRF and Ucn 1 appears to be less specific and is confounded by competing behaviors (increased locomotion, grooming, anxietyor fear-like) induced by activation of the brain $\mathrm{CRF}_{1}$ signaling pathway. This contrasts with icv Ucn 2 that does not elicit behavioral arousal or anxiogenic effects (Pelleymounter et al., 2000; Inoue et al., 2003; Zorrilla et al., 2004; Jochman et al., 2005). Several brain sites expressing high concentrations of $\mathrm{CRF}_{2}$ (Bittencourt and Sawchenko, 2000) have been identified to be 
responsive to $\mathrm{Ucns}$ resulting in a $\mathrm{CRF}_{2}$-mediated anorexigenic response, namely the lateral septum (Bakshi et al., 2007), PVN (Currie et al., 2001), VMH (Ohata et al., 2000; Fekete et al., 2007; Chen et al., 2012), medial amygdala (Fekete et al., 2007) and dorsal raphe (Weitemier and Ryabinin, 2006). In addition, hindbrain structures are involved based on the observation that Ucn 1 injected into the fourth brain ventricle is still able to reduce food intake in chronically decerebrated rats (Daniels et al., 2004). Among those, the nucleus tractus solitarius has been identified as a brainstem site responsive to Ucn 1 (Grill et al., 2000).

Analysis of changes in feeding patterns associated with the decreased food intake indicates that Ucn 2 injected icv reduced the size of the meal (increased satiation) and the rate of ingestion, whereas meal frequency was not altered in rats (Inoue et al., 2003). In addition, Ucn 3 injected icv, and even more potently, when microinjected into the PVN and $\mathrm{VMH}$, increased inter-meal interval (induction of satiety), whereas meal size was reduced (induction of satiation) at the highest dose only (Fekete et al., 2007). In the medial amygdala, Ucn 3 was shown to promote nibbling (smaller but more frequent meal) (Fekete et al., 2007), indicating the distinct modulation of feeding patterns by Ucn 2 and Ucn 3 and the influence of brain sites of action.

The physiological relevance of the brain $\mathrm{CRF}_{2}$ signaling pathways in the regulation of feeding pattern and body weight is supported by reports that $\mathrm{CRF}_{2}$ knockout mice showed increased nocturnal food intake of normal chow (Tabarin et al., 2007) and consumed more high fat food compared to their wild type littermates (Bale et al., 2003). In addition, mice with a site specific knockdown of $\mathrm{CRF}_{2}$ in the $\mathrm{VMH}$ using small hairpin RNA exhibit increased food intake under basal and stimulated conditions by an overnight fast (Chao et al., 2012). This supports a role of $\mathrm{CRF}_{2}$ in the $\mathrm{VMH}$ to curtail the cessation of eating. There is also evidence that continuous icv infusion of the $\mathrm{CRF}_{2}$ antagonist antisauvagine-30 over 13 days increased food intake by $5 \%$ in normal rats (Cullen et al., 2001), while chronic injection of a $\mathrm{CRF}_{1}$ antagonist had no effect (Ohata et al., 2002). However mice lacking Ucn 1 (Vetter et al., 2002) or Ucn 2 (Chen et al., 2006) have a normal spontaneous food intake which may merely emphasize the compensatory mechanisms by other endogenous peptide members of the CRF family as genetic deficient Ucn 3 showed elevated basal feeding and increased nocturnal food intake after overnight fasting compared with the wild-type littermates (Chao et al., 2012).

Several potential mechanisms could participate in icv Ucnsinduced anorexia. Central injection of CRF and Ucns potently suppressed gastric emptying (Stengel and Taché, 2010) and induces hyperglycemia (Brown et al., 1982; Chen et al., 2010). Both effects are known to reduce feeding. Delayed gastric emptying by slowing meal transit leads to accrual of food in the stomach and consecutively to gastric satiety signaling to the brain (Phillips and Powley, 1996) while elevated glucose exerts a direct action on glucose sensing of hypothalamic neurons regulating food intake (Levin, 2006; Cha et al., 2008). There is also evidence Ucn $1 \mathrm{icv}$ suppressed circulating acyl ghrelin (Yakabi et al., 2011), the only known peripherally produced and centrally acting orexigenic hormone (Hosoda et al., 2002; Stengel and Taché, 2012). Moreover,
Ucn 1 microinjected into the PVN increased plasma levels of leptin (Kotz et al., 2002), a potent appetite suppressant (KeenRhinehart et al., 2013). Future studies are needed to evaluate the relative influence of these hormonal and functional alterations.

Besides the reduction in food intake, accumulated evidence indicates that activation of brain CRF and Ucns signaling pathways increases energy expenditure (Richard et al., 2002; Kuperman and Chen, 2008). Sympathetically-regulated heat production in brown adipose tissue (BAT) and lipid metabolism contributes to the non-shivering thermogenic component of energy expenditure and body weight regulation in rodents (Landsberg et al., 1984). The icv injection of Ucns increases oxygen consumption in rats as assessed by indirect calorimetry and elevates body temperature resulting in increased energy expenditure (De Fanti and Martinez, 2002; Telegdy and Adamik, 2008). Microinjection studies showed that CRF sites of action to increase sympathetic nerve activity to interscapular BAT leading to BATmediated thermogenesis and energy expenditure are located in the medial preoptic area and dorsomedial hypothalamus unlike the PVN or VMH (Egawa et al., 1990; Cerri and Morrison, 2006; Chao et al., 2012). However, during food restriction, Ucn 1 microinjected into the PVN increases thermogenic capacity by elevating uncoupling protein-1 mRNA levels in BAT (Kotz et al., 2002). The peptide at this site also changes energy substrate utilization as shown by reduction of the respiratory quotient $(\mathrm{QR})$ under basal or NPY- or ghrelin-stimulated conditions (Currie et al., 2001). The $\mathrm{CRF}_{2}$ seems to play a major role in the effects on energy expenditure as mice lacking the $\mathrm{CRF}_{1}$ showed a greater reduction in body weight following a 7-day icv infusion of Ucn 1 compared to their wild type littermates (Bradbury et al., 2000). Additionally, the hyperthermic response to icv Ucn 2 and Ucn 3 was blocked by selective $\mathrm{CRF}_{2}$ receptor antagonists while $\mathrm{CRF}_{1}$ blockade had no effect (Telegdy et al., 2006). Moreover, selective depletion of $\mathrm{CRF}_{2}$ in the $\mathrm{VMH}$ reduced lipolysis and increased white fat (Chao et al., 2012).

\section{FOOD INTAKE INHIBITORY ACTIONS OF PERIPHERAL CRF AND Ucns}

In addition to the central actions of CRF and Ucns, peripheral (intraperitoneal, ip) injection of Ucns reduced food intake in several species (Asakawa et al., 1999; Weisinger et al., 2000; Wang et al., 2001; Tanaka et al., 2009) and repeated administration also lowered body weight gain in mice (Asakawa et al., 1999). The anorexigenic effect of Ucn 1 on re-feeding food intake was stronger than that of cholecystokinin (CCK), leptin, and also CRF in mice (Asakawa et al., 1999; Wang et al., 2001; Tanaka et al., 2009). Interestingly, a synergistic interaction between ip injected Ucn 1 and CCK-8 to reduce the feeding response to a fast and liquid gastric emptying has been reported in mice (Gourcerol et al., 2007). The demonstration that Ucn 1 injected peripherally displays a similar potency as after icv injection supports a peripherally initiated mode of action (Cullen et al., 2001; Sinnayah et al., 2003; Pelleymounter et al., 2004). However, it is to note that systemic doses at which the preferential $\mathrm{CRF}_{1}$ agonist CRF, and potent $\mathrm{CRF}_{1} / \mathrm{CRF}_{2}$ agonist, Ucn 1 decrease food intake are associated with conditioned taste aversion and diarrhea (Fekete et al., 2011), which are not observed at the lower anorexigenic doses of 
Ucn 1 given icv (Benoit et al., 2000; Inoue et al., 2003; Zorrilla et al., 2004).

The reduction of food intake by ip $\mathrm{Ucn} 1$ is $\mathrm{CRF}_{2}$ mediated as the selective $\mathrm{CRF}_{2}$ antagonists, antisauvagine-30 and astressin $2_{-}^{-}$ $\mathrm{B}$ blunted the reduction of food intake, whereas selective $\mathrm{CRF}_{1}$ antagonists did not (Weisinger et al., 2000; Wang et al., 2001, 2011b). In line with this finding, fasted mice lacking the $\mathrm{CRF}_{2}$ did not show a reduction of re-feeding food intake following ip injected Ucn 1 (Wang et al., 2011b). The mechanisms through which peripheral Ucn 1 exerts its anorexigenic effect do not involve capsaicin sensory afferents, unlike ip CCK-8 tested under the same conditions in mice (Wang et al., 2001). It was also shown that the slowing of gastric emptying associated with ip Ucn 1 accounts only for $35 \%$ of the reduction of food intake induced by Ucn 1 (Wang et al., 2001). It may be speculated that Ucn 1 acts through $\mathrm{CRF}_{2}$ densely expressed in appetite-/taste aversion-regulating brain structures outside the blood brain barrier, namely the area postrema (Sakai and Yamamoto, 1997; Bittencourt and Sawchenko, 2000) shown to be activated by systemic injection of Ucn 1 (Wang et al., 2000). This contention will need to be further ascertained.

With regards to Ucn 2 and $U c n$ 3, both peptides induce a rapid in onset and $\mathrm{CRF}_{2}$ mediated reduction of re-feeding food intake after a fast and also dampen ad libitum dark phase food intake with a potency of Ucn $2>\operatorname{Ucn} 3$ in rodents (Wang et al., 2001, 2011b; Gourcerol et al., 2007; Tanaka et al., 2009; Fekete et al., 2011). In contrast to ip Ucn 1, Ucn 2 given ip at an anorexigenic dose did not induce signs of taste aversion or malaise (Fekete et al., 2011). Of interest, there is a synergistic interaction between ip CCK- 8 and Ucn 2 to reduce the re-feeding response to a fast in mice which was also observed at the level of vagal activity recorded from the gastric afferents in an in vitro preparation (Gourcerol et al., 2007). This functional and electrophysiological evidence combined with the expression of $\mathrm{CRF}_{2}$ in rat nodose ganglia (Mercer et al., 1992; Lawrence et al., 2002) point toward a role of vagal signaling in the mediation of ip Ucn 2 anorexic action that will need to be ascertained using vagal deafferentation.

Additional insight into the characterization of the food intakereducing effects of peripheral administration of Ucns came from studies detailing changes in meal patterns. Using the micropellet technique, ip injection of Ucn 1 reduces the meal frequency (as a characteristic of satiety), whereas the size of the meal (as a characteristic of satiation) was less robustly altered during the re-feeding period following a 24-h fast in rats (Fekete et al., 2011). Under the same conditions, ip injection of Ucn 2 only reduced meal frequency while not altering meal size (Fekete et al., 2011). These data were recently extended to mice following ip injection of $U \mathrm{cn}$ 2 using an automated episodic food intake monitoring system for solid food: Ucn 2 reduced meal size and duration (induction of satiation) but also increased meal frequency (reduction of satiety) in overnight fasted mice (Wang et al., 2011b). Interestingly, when injected ip in freely fed animals at the beginning of the dark phase, Ucn 2 only affected satiation (reduction of meal size), whereas satiety (indicated by the number of meals) was not altered (Wang et al., 2011b) giving rise to a differential modulation of light and dark phase feeding by Ucn 2 .

\section{INVOLVEMENT OF BRAIN CRF SIGNALING PATHWAYS IN THE ANOREXIGENIC RESPONSE TO STRESS}

Accumulated evidence supports a role of brain activation of CRF signaling pathways in initiating the hypophagia and weight loss induced by various types of stressors. This was established using pharmacological approaches and to a lesser extent, genetic deletion of CRF ligand or receptors in rodents. Earlier studies showed that icv or 3rd ventricular injection of the non-selective $\mathrm{CRF}_{1} / \mathrm{CRF}_{2}$, antagonist, $\alpha$-helical $\mathrm{CRF}_{9-41}$ before exposure to stressors prevented the decreased food intake observed after acute exposure to restraint (Krahn et al., 1986; Shibasaki et al., 1988; Smagin et al., 1999), $40 \mathrm{~min}$ forced exercise (Rivest and Richard, 1990) or emotional stress induced by a communication box paradigm (Hotta et al., 1999) while having no effect on food intake under non-stressful conditions (Hotta et al., 1999). The CRF antagonist injected into the 3rd ventricle also blocked repeated restraint-induced weight loss (Smagin et al., 1999). Subsequent studies to elucidate the importance of each CRF receptor subtype in the stress-related decrease in food intake indicated that either CRF receptor subtype alone or in combination can be involved in the hypophagia depending upon the modality of the stressors. Evidence so far supports that the relative ability of selective CRF receptor subtype antagonists to block stress-related anorexia is critically dependent upon specific brain sites activated and related CRF ligands and receptor subtypes recruited by different stressors. For instance, emotional stress triggered by the communication box paradigm, foot shock and 1-h restraint was reported to involve both $\mathrm{CRF}_{1}$ and $\mathrm{CRF}_{2}$ receptors in rats as shown by partial or complete reversal induced by either icv injection of $\mathrm{CRF}_{2}$ antagonist, antisauvagine-30 or peripheral administration of the $\mathrm{CRF}_{1}$ antagonist, CRA 1000 (Hotta et al., 1999; Sekino et al., 2004). In mice, novelty/group separation stress-induced reduction of food intake was curtailed by icv pretreatment with the $\mathrm{CRF}_{1}$ antagonist, NBI- 127914 while the potent $\mathrm{CRF}_{2}$ antagonist, astressin $2-\mathrm{B}$ had no effect (Saegusa et al., 2011). Brain site specific targeting by CRF antagonists indicates that the $\mathrm{CRF}_{1}$ antagonist, NBI-27914 microinjected into the basolateral amygdala, unlike central amygdala, prevented emotional stress (rat exposed to predator)-induced decreased food intake and increased grooming while astressin $2-B$ had no effect (Jochman et al., 2005). By contrast, the $\mathrm{CRF}_{2}$ antagonist, antisauvagine-30 microinjected into the lateral septum or posterior division of the bed nucleus of the stria terminalis prevented acute restraint-induced anorexia while the selective $\mathrm{CRF}_{1}$ antagonist, antalarmin had no effect in rats (Ohata and Shibasaki, 2011). There is also evidence that $\mathrm{CRF}_{2}$ knockout mice showed an abbreviated inhibition of food intake induced by restraint stress while not being involved in the early orexigenic response (Tabarin et al., 2007).

Of (patho)physiological relevance is the demonstration that mutation in the $\mathrm{CRF}_{2}$ gene (Val411Met) was associated with an early onset of severe obesity (Challis et al., 2004). Moreover, several studies observed an association with a portion of chromosome 7 also coding the $\mathrm{CRF}_{2}$ gene (7p15-7p21) and body mass index (Wu et al., 2002), type 2 diabetes mellitus (Wiltshire et al., 2001) and also fat-free body mass (Chagnon et al., 2000). Future studies are needed to corroborate 
these findings and investigate the consequences of these associations.

\section{SUMMARY}

In summary, activation of $\mathrm{CRF}_{2}$ by Ucns reduced feeding after central as well as peripheral injection without provoking behavioral arousal or anxiogenic effects as observed for the anorexigenic action induced by the activation $\mathrm{CRF}^{-\mathrm{CRF}_{1}}$ signaling pathways. Brain sites of action of Ucns involve the lateral septum, PVN, VMH, medial amygdala, dorsal raphe and nucleus tractus solitarius. Both, $\mathrm{CRF}_{1}$ and $\mathrm{CRF}_{2}$ receptor activation contributes to the reduction of food intake associated with exposure to various stressors. Their respective involvement is stressors and brain sites specific mostly in relation with endogenous CRF ligands and receptors recruited under the condition of stress. Still little is known whether peripheral $U \mathrm{cn}-\mathrm{CRF}_{2}$ signaling plays a role in the food intake response to visceral stressors. More research is needed using site specific knockout or overexpression of CRF receptors in order to address this issue and investigate the impact on food intake and body weight.

\section{ACKNOWLEDGMENTS}

This work was supported by NIH R01 DK-33061, NIH Center Grant DK-41301 (Animal Core), VA Research Career Scientist (Yvette Taché), German Research Foundation STE 1765/3-1 (Andreas Stengel) and Charité University Funding UFF 89-441176 (Andreas Stengel).

\section{REFERENCES}

Ardati, A., Goetschy, V., Gottowick, J., Henriot, S., Valdenaire, O., Deuschle, U., et al. (1999). Human CRF2 alpha and beta splice variants: pharmacological characterization using radioligand binding and a luciferase gene expression assay. Neuropharmacology 38, 441-448. doi: 10.1016/S0028-3908(98)00201-9

Asakawa, A., Inui, A., Ueno, N., Makino, S., Fujino, M. A., and Kasuga, M. (1999). Urocortin reduces food intake and gastric emptying in lean and ob/ob obese mice. Gastroenterology 116, 1287-1292. doi: 10.1016/S0016-5085(99)70491-9

Bakshi, V. P., Newman, S. M., Smith-Roe, S., Jochman, K. A., and Kalin, N. H. (2007). Stimulation of lateral septum CRF2 receptors promotes anorexia and stress-like behaviors: functional homology to CRF1 receptors in basolateral amygdala. J. Neurosci. 27, 10568-10577. doi: 10.1523/JNEUROSCI.304406.2007

Bale, T. L., Anderson, K. R., Roberts, A. J., Lee, K. F., Nagy, T. R., and Vale, W. W. (2003). Corticotropin-releasing factor receptor-2-deficient mice display abnormal homeostatic responses to challenges of increased dietary fat and cold. Endocrinology 144, 2580-2587. doi: 10.1210/en.2002-0091

Bale, T. L., and Vale, W. W. (2004). CRF and CRF receptors: role in stress responsivity and other behaviors. Annu. Rev. Pharmacol. Toxicol. 44, 525-557. doi: 10.1146/annurev.pharmtox.44.101802.121410

Basa, N. R., Wang, L., Arteaga, J. R., Heber, D., Livingston, E. H., and Taché, Y. (2003). Bacterial lipopolysaccharide shifts fasted plasma ghrelin to postprandial levels in rats. Neurosci. Lett. 343, 25-28. doi: 10.1016/S0304-3940(03)00312-4

Beckerman, M. A., Van Kempen, T. A., Justice, N. J., Milner, T. A., and Glass, M. J. (2013). Corticotropin-releasing factor in the mouse central nucleus of the amygdala: ultrastructural distribution in NMDA-NR1 receptor subunit expressing neurons as well as projection neurons to the bed nucleus of the stria terminalis. Exp. Neurol. 239, 120-132. doi: 10.1016/j.expneurol.2012.10.009

Benoit, S. C., Thiele, T. E., Heinrichs, S. C., Rushing, P. A., Blake, K. A., and Steeley, R. J. (2000). Comparison of central administration of corticotropin-releasing hormone and urocortin on food intake, conditioned taste aversion, and c-Fos expression. Peptides 21, 345-351. doi: 10.1016/S0196-9781(00)00153-4

Bittencourt, J. C., and Sawchenko, P. E. (2000). Do centrally administered neuropeptides access cognate receptors?: an analysis in the central corticotropinreleasing factor system. J. Neurosci. 20, 1142-1156.
Bittencourt, J. C., Vaughan, J., Arias, C., Rissman, R. A., Vale, W. W., and Sawchenko, P. E. (1999). Urocortin expression in rat brain: evidence against a pervasive relationship of urocortin-containing projections with targets bearing type 2 CRF receptors. J. Comp. Neurol. 415, 285-312. doi: 10.1002/(SICI)10969861(19991220)415:3\%3C285::AID-CNE1\%3E3.3.CO;2-S

Bonaz, B., and Rivest, S. (1998). Effect of a chronic stress on CRF neuronal activity and expression of its type 1 receptor in the rat brain. Am. J. Physiol. 275, R1438-R1449.

Boorse, G. C., and Denver, R. J. (2006). Widespread tissue distribution and diverse functions of corticotropin-releasing factor and related peptides. Gen. Comp. Endocrinol. 146, 9-18. doi: 10.1016/j.ygcen.2005.11.014

Bradbury, M. J., McBurnie, M. I., Denton, D. A., Lee, K. F., and Vale, W. W. (2000). Modulation of urocortin-induced hypophagia and weight loss by corticotropinreleasing factor receptor 1 deficiency in mice. Endocrinology 141, 2715-2724. doi: 10.1210/en.141.8.2715

Brown, M. R., Fisher, L. A., Spiess, J., Rivier, C., Rivier, J., and Vale, W. (1982). Corticotropin-releasing factor: actions on the sympathetic nervous system and metabolism. Endocrinology 111, 928-931. doi: 10.1210/endo-111-3-928

Buckinx, R., Adriaensen, D., Nassauw, L. V., and Timmermans, J. P. (2011). Corticotrophin-releasing factor, related peptides, and receptors in the normal and inflamed gastrointestinal tract. Front. Neurosci. 5:54. doi: 10.3389/fnins.2011.00054

Calvez, J., Fromentin, G., Nadkarni, N., Darcel, N., Even, P., Tome, D., et al. (2011). Inhibition of food intake induced by acute stress in rats is due to satiation effects. Physiol. Behav. 104, 675-683. doi: 10.1016/j.physbeh.2011.07.012

Cerri, M., and Morrison, S. F. (2006). Corticotropin releasing factor increases in brown adipose tissue thermogenesis and heart rate through dorsomedial hypothalamus and medullary raphe pallidus. Neuroscience 140, 711-721. doi: 10.1016/j.neuroscience.2006.02.027

Cha, S. H., Wolfgang, M., Tokutake, Y., Chohnan, S., and Lane, M. D. (2008). Differential effects of central fructose and glucose on hypothalamic malonylCoA and food intake. Proc. Natl. Acad. Sci. U.S.A. 105, 16871-16875. doi: 10.1073/pnas.0809255105

Chagnon, Y. C., Borecki, I. B., Perusse, L., Roy, S., Lacaille, M., Chagnon, M., et al. (2000). Genome-wide search for genes related to the fat-free body mass in the Quebec family study. Metabolism 49, 203-207. doi: 10.1016/S00260495(00)91299-X

Challis, B. G., Luan, J., Keogh, J., Wareham, N. J., Farooqi, I. S., and O’Rahilly, S. (2004). Genetic variation in the corticotrophin-releasing factor receptors: identification of single-nucleotide polymorphisms and association studies with obesity in UK Caucasians. Int. J. Obes. Relat. Metab. Disord. 28, 442-446. doi: 10.1038/sj.ijo.0802564

Chao, H., Digruccio, M., Chen, P., and Li, C. (2012). Type 2 corticotropin-releasing factor receptor in the ventromedial nucleus of hypothalamus is critical in regulating feeding and lipid metabolism in white adipose tissue. Endocrinology 153, 166-176. doi: 10.1210/en.2011-1312

Chatzaki, E., Crowe, P. D., Wang, L., Million, M., Taché, Y., and Grigoriadis, D. E. (2004). CRF receptor type 1 and 2 expression and anatomical distribution in the rat colon. J. Neurochem. 90, 309-316. doi: 10.1111/j.1471-4159.2004.02490.x

Chen, A., Zorrilla, E., Smith, S., Rousso, D., Levy, C., Vaughan, J., et al. (2006). Urocortin 2-deficient mice exhibit gender-specific alterations in circadian hypothalamus-pituitary-adrenal axis and depressive-like behavior. J. Neurosci. 26, 5500-5510. doi: 10.1523/JNEUROSCI.3955-05.2006

Chen, A. M., Perrin, M. H., Digruccio, M. R., Vaughan, J. M., Brar, B. K., Arias, C. M., et al. (2005). A soluble mouse brain splice variant of type 2alpha corticotropin-releasing factor (CRF) receptor binds ligands and modulates their activity. Proc. Natl. Acad. Sci. U.S.A. 102, 2620-2625. doi: 10.1073/pnas.0409583102

Chen, P., Hover, C. V., Lindberg, D., and Li, C. (2012). Central urocortin 3 and type 2 corticotropin-releasing factor receptor in the regulation of energy homeostasis: critical involvement of the ventromedial hypothalamus. Front. Endocrinol. (Lausanne). 3:180. doi: 10.3389/fendo.2012.00180

Chen, P., Vaughan, J., Donaldson, C., Vale, W., and Li, C. (2010). Injection of Urocortin 3 into the ventromedial hypothalamus modulates feeding, blood glucose levels, and hypothalamic POMC gene expression but not the HPA axis. Am. J. Physiol. Endocrinol. Metab. 298, E337-E345. doi: 10.1152/ajpendo. 00402.2009

Contarino, A., Dellu, F., Koob, G. F., Smith, G. W., Lee, K. F., Vale, W. W., et al. (2000). Dissociation of locomotor activation and suppression of food intake 
induced by CRF in CRFR1-deficient mice. Endocrinology 141, 2698-2702. doi: 10.1210/endo.141.7.7653

Cullen, M. J., Ling, N., Foster, A. C., and Pelleymounter, M. A. (2001). Urocortin, corticotropin releasing factor-2 receptors and energy balance. Endocrinology. 142, 992-999. doi: 10.1210/endo.142.3.7989

Currie, P. J., Coscina, D. V., Bishop, C., Coiro, C. D., Koob, G. F., Rivier, J., et al. (2001). Hypothalamic paraventricular nucleus injections of urocortin alter food intake and respiratory quotient. Brain Res. 916, 222-228. doi: 10.1016/S00068993(01)02851-7

Dallman, M. F. (2010). Stress-induced obesity and the emotional nervous system. Trends Endocrinol. Metab. 21, 159-165. doi: 10.1016/j.tem.2009.10.004

Daniels, D., Markison, S., Grill, H. J., and Kaplan, J. M. (2004). Central structures necessary and sufficient for ingestive and glycemic responses to Urocortin I administration. J. Neurosci. 24, 11457-11462. doi: 10.1523/JNEUROSCI.270204.2004

Dautzenberg, F. M., Higelin, J., Wille, S., and Brauns, O. (2004). Molecular cloning and functional expression of the mouse CRF2(a) receptor splice variant. Regul. Pept. 121, 89-97. doi: 10.1016/j.regpep.2004.04.009

Dautzenberg, F. M., Kilpatrick, G. J., Hauger, R. L., and Moreau, J. (2001). Molecular biology of the CRH receptors- in the mood. Peptides 22, 753-760. doi: 10.1016/S0196-9781(01)00388-6

De Fanti, B. A., and Martinez, J. A. (2002). Central urocortin activation of sympathetic-regulated energy metabolism in Wistar rats. Brain Res. 930, 37-41. doi: 10.1016/S0006-8993(01)03401-1

De Groot, J., and Harris, G. W. (1950). Hypothalmic control of the anterior pituitary gland and blood lymphocytes. J. Physiol. 111, 335-346.

De Souza, E. B. (1995). Corticotropin-releasing factor receptors: physiology, pharmacology, biochemistry and role in central nervous system and immune disorders. Psychoneuroendocrinology. 20, 789-819. doi: 10.1016/03064530(95)00011-9

Diaz, I., and Smani, T. (2013). New insights into the mechanisms underlying vascular and cardiac effects of urocortin. Curr. Vasc. Pharmacol. 11, 457-464. doi: 10.2174/1570161111311040009

Dunn, A. J., and Berridge, C. W. (1990). Physiological and behavioral responses to corticotropin-releasing factor administration: is CRF a mediator of anxiety or stress responses? Brain Res. Brain Res. Rev. 15, 71-100. doi: 10.1016/01650173(90)90012-D

Egawa, M., Yoshimatsu, H., and Bray, G. A. (1990). Preoptic area injection of corticotropin-releasing hormone stimulates sympathetic activity. Am. J. Physiol. 259, R799-R806.

Fekete, E. M., Inoue, K., Zhao, Y., Rivier, J. E., Vale, W. W., Szucs, A., et al. (2007). Delayed satiety-like actions and altered feeding microstructure by a selective type 2 corticotropin-releasing factor agonist in rats: intra-hypothalamic urocortin 3 administration reduces food intake by prolonging the post-meal interval. Neuropsychopharmacology 32, 1052-1068. doi: 10.1038/sj.npp.1301214

Fekete, E. M., Zhao, Y., Szucs, A., Sabino, V., Cottone, P., Rivier, J., et al. (2011). Systemic urocortin 2, but not urocortin 1 or stressin 1-A, suppresses feeding via CRF2 receptors without malaise and stress. Br. J. Pharmacol. 164, 1959-1975. doi: 10.1111/j.1476-5381.2011.01512.x

Gourcerol, G., Wang, L., Wang, Y. H., Million, M., and Taché, Y. (2007). Urocortins and cholecystokinin-8 act synergistically to increase satiation in lean but not obese mice: involvement of corticotropin-releasing factor receptor-2 pathway. Endocrinology 148, 6115-6123. doi: 10.1210/en.2007-0678

Grace, C. R., Perrin, M. H., Cantle, J. P., Vale, W. W., Rivier, J. E., and Riek, R. (2007). Common and divergent structural features of a series of corticotropin releasing factor-related peptides. J. Am. Chem. Soc. 129, 16102-16114. doi: $10.1021 /$ ja0760933

Grill, H. J., Markison, S., Ginsberg, A., and Kaplan, J. M. (2000). Long-term effects on feeding and body weight after stimulation of forebrain or hindbrain CRH receptors with urocortin. Brain Res. 867, 19-28. doi: 10.1016/S00068993(00)02193-4

Guillemin, R., and Rosenberg, B. (1955). Humoral hypothalamic control of anterior pituitary: a study with combined tissue cultures. Endocrinology 57, 599-607. doi: 10.1210/endo-57-5-599

Habib, K. E., Weld, K. P., Rice, K. C., Pushkas, J., Champoux, M., Listwak, S., et al. (2000). Oral administration of a corticotropin-releasing hormone receptor antagonist significantly attenuates behavioral, neuroendocrine, and autonomic responses to stress in primates. Proc. Natl. Acad. Sci. U.S.A. 97, 6079-6084. doi: 10.1073/pnas.97.11.6079
Harris, G. W. (1950). The hypothalamus and endocrine glands. Br. Med. Bull. 6 , $345-350$.

Hauger, R. L., Grigoriadis, D. E., Dallman, M. F., Plotsky, P. M., Vale, W. W., and Dautzenberg, F. M. (2003). International Union of Pharmacology. XXXVI. Current status of the nomenclature for receptors for corticotropin-releasing factor and their ligands. Pharmaco Rev. 55, 21-26. doi: 10.1124/pr.55.1.3

Heinrichs, S. C., Min, H., Tamraz, S., Carmouche, M., Boehme, S. A., and Vale, W. W. (1997). Anti-sexual and anxiogenic behavioral consequences of corticotropin-releasing factor overexpression are centrally mediated. Psychoneuroendocrinology 22, 215-224. doi: 10.1016/S0306-4530(97)00030-9

Hillhouse, E. W., and Grammatopoulos, D. K. (2006). The molecular mechanisms underlying the regulation of the biological activity of corticotropin-releasing hormone receptors: implications for physiology and pathophysiology. Endocr. Rev. 27, 260-286. doi: 10.1210/er.2005-0034

Hosoda, H., Kojima, M., and Kangawa, K. (2002). Ghrelin and the regulation of food intake and energy balance. Mol. Interv. 2, 494-503. doi: 10.1124/mi.2.8.494

Hotta, M., Shibasaki, T., Arai, K., and Demura, H. (1999). Corticotropinreleasing factor receptor type 1 mediates emotional stress-induced inhibition of food intake and behavioral changes in rats. Brain Res. 823, 221-225. doi: 10.1016/S0006-8993(99)01177-4

Hsu, S. Y., and Hsueh, A. J. (2001). Human stresscopin and stresscopin-related peptide are selective ligands for the type 2 corticotropin-releasing hormone receptor. Nat. Med. 7, 605-611. doi: 10.1038/87936

Imaki, T., Katsumata, H., Miyata, M., Naruse, M., Imaki, J., and Minami, S. (2001). Expression of corticotropin-releasing hormone type 1 receptor in paraventricular nucleus after acute stress. Neuroendocrinology 73, 293-301. doi: $10.1159 / 000054646$

Inoue, K., Valdez, G. R., Reyes, T. M., Reinhardt, L. E., Tabarin, A., Rivier, J., et al. (2003). Human urocortin II, a selective agonist for the type 2 corticotropinreleasing factor receptor, decreases feeding and drinking in the rat. J. Pharmacol. Exp. Ther. 305, 385-393. doi: 10.1124/jpet.102.047712

Jochman, K. A., Newman, S. M., Kalin, N. H., and Bakshi, V. P. (2005). Corticotropin-releasing factor-1 receptors in the basolateral amygdala mediate stress-induced anorexia. Behav. Neurosci. 119, 1448-1458. doi: 10.1037/07357044.119.6.1448

Justice, N. J., Yuan, Z. F., Sawchenko, P. E., and Vale, W. (2008). Type 1 corticotropin-releasing factor receptor expression reported in BAC transgenic mice: implications for reconciling ligand-receptor mismatch in the central corticotropin-releasing factor system. J. Comp. Neurol. 511, 479-496. doi: $10.1002 /$ cne. 21848

Keen-Rhinehart, E., Ondek, K., and Schneider, J. E. (2013). Neuroendocrine regulation of appetitive ingestive behavior. Front. Neurosci. 7:213. doi: $10.3389 /$ fnins.2013.00213

Kimura, T., Amano, T., Uehara, H., Ariga, H., Ishida, T., Torii, A., et al. (2007). Urocortin I is present in the enteric nervous system and exerts an excitatory effect via cholinergic and serotonergic pathways in the rat colon. Am. J. Physiol. Gastrointest. Liver Physiol. 293, G903-G910. doi: 10.1152/ajpgi.00066.2007

Kinzig, K. P., Hargrave, S. L., and Honors, M. A. (2008). Binge-type eating attenuates corticosterone and hypophagic responses to restraint stress. Physiol. Behav. 95, 108-113. doi: 10.1016/j.physbeh.2008.04.026

Konishi, S., Kasagi, Y., Katsumata, H., Minami, S., and Imaki, T. (2003). Regulation of corticotropin-releasing factor (CRF) type-1 receptor gene expression by CRF in the hypothalamus. Endocr. J. 50, 21-36. doi: 10.1507/endocrj.50.21

Koob, G. F., and Heinrichs, S. C. (1999). A role for corticotropin releasing factor and urocortin in behavioral responses to stressors. Brain Res. 848, 141-152. doi: 10.1016/S0006-8993(99)01991-5

Korosi, A., Kozicz, T., Richter, J., Veening, J. G., Olivier, B., and Roubos, E. W. (2007). Corticotropin-releasing factor, urocortin 1, and their receptors in the mouse spinal cord. J. Comp. Neurol. 502, 973-989. doi: 10.1002/cne.21347

Kostich, W. A., Chen, A., Sperle, K., and Largent, B. L. (1998). Molecular identification and analysis of a novel human corticotropin-releasing factor (CRF) receptor: the CRF2gamma receptor. Mol. Endocrinol. 12, 1077-1085.

Kotz, C. M., Wang, C., Levine, A. S., and Billington, C. J. (2002). Urocortin in the hypothalamic PVN increases leptin and affects uncoupling proteins-1 and -3 in rats. Am. J. Physiol. Regul. Integr. Comp. Physiol. 282, R546-R551. doi: 10.1152/ajpregu.00436.2001

Kozicz, T., and Arimura, A. (2002). Distribution of urocortin in the rat's gastrointestinal tract and its colocalization with tyrosine hydroxylase. Peptides 23, 515-521. doi: 10.1016/S0196-9781(01)00639-8 
Kozicz, T., Yanaihara, H., and Arimura, A. (1998). Distribution of urocortinlike immunoreactivity in the central nervous system of the rat. J. Comp. Neurol. 391, 1-10. doi: 10.1002/(SICI)1096-9861(19980202)391:1\%3C1::AIDCNE1\%3E3.0.CO;2-6

Krahn, D. D., Gosnell, B. A., Grace, M., and Levine, A. S. (1986). CRF antagonist partially reverses CRF- and stress-induced effects on feeding. Brain Res. Bull. 17, 285-289. doi: 10.1016/0361-9230(86)90233-9

Kumar, J., Chuang, J. C., Na, E. S., Kuperman, A., Gillman, A. G., Mukherjee, S., et al. (2013). Differential effects of chronic social stress and fluoxetine on meal patterns in mice. Appetite 64, 81-88. doi: 10.1016/j.appet.2012.12.023

Kuperman, Y., and Chen, A. (2008). Urocortins: emerging metabolic and energy homeostasis perspectives. Trends Endocrinol. Metab. 19, 122-129. doi: 10.1016/j.tem.2007.12.002

Landsberg, L., Saville, M. E., and Young, J. B. (1984). Sympathoadrenal system and regulation of thermogenesis. Am. J. Physiol. 247, E181-E189.

Lawrence, A. J., Krstew, E. V., Dautzenberg, F. M., and Ruhmann, A. (2002). The highly selective $\operatorname{CRF}(2)$ receptor antagonist K41498 binds to presynaptic CRF(2) receptors in rat brain. Br. J. Pharmacol. 136, 896-904. doi: 10.1038/sj.bjp.0704783

Levin, B. E. (2006). Metabolic sensing neurons and the control of energy homeostasis. Physiol. Behav. 89, 486-489. doi: 10.1016/j.physbeh.2006.07.003

Lewis, K., Li, C., Perrin, M. H., Blount, A., Kunitake, K., Donaldson, C., et al. (2001). Identification of urocortin III, an additional member of the corticotropin-releasing factor (CRF) family with high affinity for the CRF2 receptor. Proc. Natl. Acad. Sci. U.S.A. 98, 7570-7575. doi: 10.1073/pnas. 121165198

Li, C., Chen, P., Vaughan, J., Blount, A., Chen, A., Jamieson, P. M., et al. (2003). Urocortin III is expressed in pancreatic beta-cells and stimulates insulin and glucagon secretion. Endocrinology. 144, 3216-3224. doi: 10.1210/en. 2002-0087

Li, C., Vaughan, J., Sawchenko, P. E., and Vale, W. W. (2002). Urocortin IIIimmunoreactive projections in rat brain: partial overlap with sites of type 2 corticotrophin-releasing factor receptor expression. J. Neurosci. 22, 991-1001.

Liapakis, G., Venihaki, M., Margioris, A., Grigoriadis, D., and Gkountelias, K. (2011). Members of CRF family and their receptors: from past to future. Curr. Med. Chem. 18, 2583-2600. doi: 10.2174/092986711795933704

Liu, S., Gao, N., Hu, H. Z., Wang, X., Wang, G. D., Fang, X., et al. (2006). Distribution and chemical coding of corticotropin-releasing factorimmunoreactive neurons in the guinea pig enteric nervous system. J. Comp. Neurol. 494, 63-74. doi: 10.1002/cne.20781

Lovejoy, D. A., and de Lannoy, L. (2013). Evolution and phylogeny of the corticotropin-releasing factor (CRF) family of peptides: Expansion and specialization in the vertebrates. J. Chem. Neuroanat. 54, 50-56. doi: 10.1016/j.jchemneu.2013.09.006

Lutter, M., Sakata, I., Osborne-Lawrence, S., Rovinsky, S. A., Anderson, J. G., Jung, S., et al. (2008). The orexigenic hormone ghrelin defends against depressive symptoms of chronic stress. Nat. Neurosci. 11, 752-753. doi: 10.1038/ nn.2139

Mano-Otagiri, A., and Shibasaki, T. (2004). Distribution of urocortin 2 and urocortin 3 in rat brain. J. Nippon Med. Sch. 71, 358-359. doi: 10.1272/jnms.71.358

Markovic, D., and Grammatopoulos, D. K. (2010). Characterization of structural determinants of type 1 corticotropin releasing hormone (CRH) receptor signalling properties. Methods Mol. Biol. 634, 285-307. doi: 10.1007/978-160761-652-8_21

Mercer, J. G., Lawrence, C. B., and Copeland, P. A. (1992). Corticotropinreleasing factor binding sites undergo axonal transport in the rat vagus nerve. J. Neuroendocrinol. 4, 281-286. doi: 10.1111/j.1365-2826.1992.tb00169.x

Miyata, I., Shiota, C., Chaki, S., Okuyama, S., and Inagami, T. (2001). Localization and characterization of a short isoform of the corticotropin-releasing factor receptor type 2alpha (CRF(2)alpha-tr) in the rat brain. Biochem. Biophys. Res. Commun. 280, 553-557. doi: 10.1006/bbrc.2000.4112

Miyata, I., Shiota, C., Ikeda, Y., Oshida, Y., Chaki, S., Okuyama, S., et al. (1999). Cloning and characterization of a short variant of the corticotropin-releasing factor receptor subtype from rat amygdala. Biochem. Biophys. Res. Commun. 256, 692-696. doi: 10.1006/bbrc. 1999.0392

Morin, S. M., Ling, N., Liu, X. J., Kahl, S. D., and Gehlert, D. R. (1999). Differential distribution of urocortin- and corticotropin-releasing factor-like immunoreactivities in the rat brain. Neuroscience 92, 281-291. doi: 10.1016/S03064522(98)00732-5
Ohata, H., Arai, K., and Shibasaki, T. (2002). Effect of chronic administration of a CRF(1) receptor antagonist, CRA1000, on locomotor activity and endocrine responses to stress. Eur. J. Pharmacol. 457, 201-206. doi: 10.1016/S00142999(02)02663-8

Ohata, H., and Shibasaki, T. (2004). Effects of urocortin 2 and 3 on motor activity and food intake in rats. Peptides 25, 1703-1709. doi: 10.1016/j.peptides.2004.05.023

Ohata, H., and Shibasaki, T. (2011). Involvement of CRF2 receptor in the brain regions in restraint-induced anorexia. Neuroreport 22, 494-498. doi: 10.1097/WNR.0b013e3283487467

Ohata, H., Suzuki, K., Oki, Y., and Shibasaki, T. (2000). Urocortin in the ventromedial hypothalamic nucleus acts as an inhibitor of feeding behavior in rats. Brain Res. 861, 1-7. doi: 10.1016/S0006-8993(99)02378-1

Onorati, F., Chen-Scarabelli, C., Knight, R., Stephanou, A., Mohanti, B., Santini, F., et al. (2013). Targeting urocortin signaling pathways to enhance cardioprotection: is it time to move from bench to bedside? Cardiovasc. Drugs Ther. 27, 451-463. doi: 10.1007/s10557-013-6468-7

Overman, E. L., Rivier, J. E., and Moeser, A. J. (2012). CRF induces intestinal epithelial barrier injury via the release of mast cell proteases and TNF-alpha. PLoS ONE 7:e39935. doi: 10.1371/journal.pone.0039935

Pelleymounter, M. A., Joppa, M., Carmouche, M., Cullen, M. J., Brown, B., Murphy, B., et al. (2000). Role of corticotropin-releasing factor (CRF) receptors in the anorexic syndrome induced by CRF. J. Pharmacol. Exp. Ther. 293, 799-806.

Pelleymounter, M. A., Joppa, M., Ling, N., and Foster, A. C. (2004). Behavioral and neuroendocrine effects of the selective CRF2 receptor agonists urocortin II and urocortin III. Peptides 25, 659-666. doi: 10.1016/j.peptides.2004.01.008

Perrin, M. H., and Vale, W. W. (1999). Corticotropin releasing factor receptors and their ligand family. Ann. N.Y. Acad. Sci. 885, 312-328. doi: 10.1111/j.17496632.1999.tb08687.x

Phillips, R. J., and Powley, T. L. (1996). Gastric volume rather than nutrient content inhibits food intake. Am. J. Physiol. 271, R766-R769.

Pisarchik, A., and Slominski, A. (2004). Molecular and functional characterization of novel CRFR1 isoforms from the skin. Eur. J. Biochem. 271, 2821-2830. doi: 10.1111/j.1432-1033.2004.04216.x

Pisarchik, A., and Slominski, A. T. (2001). Alternative splicing of CRH-R1 receptors in human and mouse skin: identification of new variants and their differential expression. FASEB J. 15, 2754-2756. doi: 10.1096/fj.01-0487fje

Reyes, T. M., Lewis, K., Perrin, M. H., Kunitake, K. S., Vaughan, J., Arias, C. A., et al. (2001). Urocortin II: a member of the corticotropin-releasing factor (CRF) neuropeptide family that is selectively bound by type 2 CRF receptors. Proc. Natl. Acad. Sci. U.S.A. 98, 2843-2848. doi: 10.1073/pnas. 051626398

Richard, D., Lin, Q., and Timofeeva, E. (2002). The corticotropin-releasing factor family of peptides and CRF receptors: their roles in the regulation of energy balance. Eur. J. Pharmacol. 440, 189-197. doi: 10.1016/S0014-2999(02)01428-0

Rivest, S., and Richard, D. (1990). Involvement of corticotropin-releasing factor in the anorexia induced by exercise. Brain Res. Bull. 25, 169-172. doi: 10.1016/0361-9230(90)90270-A

Rybkin, I. I., Zhou, Y., Volaufova, J., Smagin, G. N., Ryan, D. H., and Harris, R. B. (1997). Effect of restraint stress on food intake and body weight is determined by time of day. Am. J. Physiol. 273, R1612-R1622.

Saegusa, Y., Takeda, H., Muto, S., Nakagawa, K., Ohnishi, S., Sadakane, C., et al. (2011). Decreased plasma ghrelin contributes to anorexia following novelty stress. Am. J. Physiol. Endocrinol. Metab. 301, E685-E696. doi: 10.1152/ajpendo.00121.2011

Saffran, M., Schally, A. V., and Benfey, B. G. (1955). Stimulation of the release of corticotropin from the adenohypophysis by a neurohypophysial factor. Endocrinology 57, 439-444. doi: 10.1210/endo-57-4-439

Sakai, N., and Yamamoto, T. (1997). Conditioned taste aversion and c-fos expression in the rat brainstem after administration of various USs. Neuroreport 8 , 2215-2220. doi: 10.1097/00001756-199707070-00025

Sekino, A., Ohata, H., Mano-Otagiri, A., Arai, K., and Shibasaki, T. (2004). Both corticotropin-releasing factor receptor type 1 and type 2 are involved in stressinduced inhibition of food intake in rats. Psychopharmacology (Berl.) 176, 30-38. doi: 10.1007/s00213-004-1863-1

Selye, H. (1936). A syndrome produced by diverse nocuous agents. Nature 138, 32. doi: $10.1038 / 138032 \mathrm{a} 0$

Selye, H. (1976). Stress in Health and Diseases. Boston, MA; London: Butterworths. Shah, N. S., Pugh, P. C., Nam, H., Rosenthal, D. T., van Wijk, D., Gaszner, B., et al. (2013). A subset of presympathetic-premotor neurons within the 
centrally projecting Edinger-Westphal nucleus expresses urocortin-1. J. Chem. Neuroanat. 52, 25-35. doi: 10.1016/j.jchemneu.2013.04.004

Shibasaki, T., Yamauchi, N., Kato, Y., Masuda, A., Imaki, T., Hotta, M., et al. (1988). Involvement of corticotropin-releasing factor in restraint stress-induced anorexia and reversion of the anorexia by somatostatin in the rat. Life Sci. 43, 1103-1110. doi: 10.1016/0024-3205(88)90468-7

Sinnayah, P., Blair-West, J. R., McBurnie, M. I., McKinley, M. J., Oldfield, B. J., Rivier, J., et al. (2003). The effect of urocortin on ingestive behaviours and brain Fos immunoreactivity in mice. Eur. J. Neurosci. 18, 373-382. doi: 10.1046/j.1460-9568.2003.02760.x

Smagin, G. N., Howell, L. A., Redmann, S. Jr., Ryan, D. H., and Harris, R. B. (1999). Prevention of stress-induced weight loss by third ventricle CRF receptor antagonist. Am. J. Physiol. 276, R1461-R1468.

Smagin, G. N., Howell, L. A., Ryan, D. H., De Souza, E. B., and Harris, R. B. (1998). The role of CRF2 receptors in corticotropin-releasing factor- and urocortin-induced anorexia. Neuroreport 9, 1601-1606. doi: 10.1097/00001756199805110-00063

Spina, M., Merlo-Pich, E., Chan, R. K., Basso, A. M., Rivier, J., Vale, W., et al. (1996). Appetite-suppressing effects of urocortin, a CRF-related neuropeptide. Science 273, 1561-1564. doi: 10.1126/science.273.5281.1561

Stengel, A., Goebel, M., Million, M., Stenzel-Poore, M. P., Kobelt, P., Mönnikes, H., et al. (2009). CRF over-expressing mice exhibit reduced neuronal activation in the arcuate nucleus and food intake in response to fasting. Endocrinology 150, 153-160. doi: 10.1210/en.2008-0723

Stengel, A., Goebel, M., Wang, L., Reeve, J. R., Jr., Taché, Y., and Lambrecht, N. W. (2010). Lipopolysaccharide differentially decreases plasma acyl and desacyl ghrelin levels in rats: Potential role of the circulating ghrelin-acylating enzyme GOAT. Peptides 31, 1689-1696. doi: 10.1016/j.peptides.2010.06.015

Stengel, A., Goebel-Stengel, M., Wang, L., Luckey, A., Hu, E., Rivier, J., et al. (2011). Central administration of pan-somatostatin agonist ODT8-SST prevents abdominal surgery-induced inhibition of circulating ghrelin, food intake and gastric emptying in rats. Neurogastroenterol. Motil. 23, e294-e308. doi: $10.1111 / j .1365-2982.2011 .01721 . x$

Stengel, A., and Taché, Y. (2010). Corticotropin-releasing factor signaling and visceral response to stress. Exp. Biol. Med. (Maywood). 235, 1168-1178. doi: 10.1258/ebm.2010.009347

Stengel, A., and Taché, Y. (2012). Yin and Yang - the Gastric X/A-like cell as possible dual regulator of food intake. J. Neurogastroenterol. Motil. 18, 138-149. doi: 10.5056/jnm.2012.18.2.138

Suman-Chauhan, N., Carnell, P., Franks, R., Webdale, L., Gee, N. S., McNulty, S., et al. (1999). Expression and characterisation of human and rat CRF2alpha receptors. Eur. J. Pharmacol. 379, 219-227. doi: 10.1016/S0014-2999(99) 00505-1

Tabarin, A., Diz-Chaves, Y., Consoli, D., Monsaingeon, M., Bale, T. L., Culler, M. D., et al. (2007). Role of the corticotropin-releasing factor receptor type 2 in the control of food intake in mice: a meal pattern analysis. Eur. J. Neurosci. 26, 2303-2314. doi: 10.1111/j.1460-9568.2007.05856.x

Taché, Y., and Bonaz, B. (2007). Corticotropin-releasing factor receptors and stress-related alterations of gut motor function. J. Clin. Invest. 117, 33-40. doi: $10.1172 / J C I 30085$

Taché, Y., and Perdue, M. H. (2004). Role of peripheral CRF signalling pathways in stress-related alterations of gut motility and mucosal function. Neurogastroenterol. Motil. 16(Suppl 1), 137-142. doi: 10.1111/j.17433150.2004.00490.x

Tanaka, C., Asakawa, A., Ushikai, M., Sakoguchi, T., Amitani, H., Terashi, M., et al. (2009). Comparison of the anorexigenic activity of CRF family peptides. Biochem. Biophys. Res. Commun. 390, 887-891. doi: 10.1016/j.bbrc.2009.10.069

Telegdy, G., and Adamik, A. (2008). Involvement of CRH receptors in urocortin-induced hyperthermia. Peptides 29, 1937-1942. doi: 10.1016/j.peptides.2008.07.028

Telegdy, G., Adamik, A., and Toth, G. (2006). The action of urocortins on body temperature in rats. Peptides 27, 2289-2294. doi: 10.1016/j.peptides.2006.03.022

Turnbull, A. V., and Rivier, C. (1997). Corticotropin-releasing factor (CRF) and endocrine responses to stress: CRF receptors, binding protein, and related peptides. Proc. Soc. Exp. Biol. Med. 215, 1-10. doi: 10.3181/00379727-21544108

Vale, W., Spiess, J., Rivier, C., and Rivier, J. (1981). Characterization of a 41-residue ovine hypothalamic peptide that stimulates secretion of corticotropin and betaendorphin. Science 213, 1394-1397. doi: 10.1126/science.6267699
Valentino, R. J., Page, M. E., Luppi, P. H., Zhu, Y., Van Bockstaele, E., and Aston-Jones, G. (1994). Evidence for widespread afferents to Barrington's nucleus, a brainstem region rich in corticotropin-releasing hormone neurons. Neuroscience 62, 125-143. doi: 10.1016/0306-4522(94)90320-4

van der Meulen, T., Xie, R., Kelly, O. G., Vale, W. W., Sander, M., and Huising, M. O. (2012). Urocortin 3 marks mature human primary and embryonic stem cell-derived pancreatic alpha and beta cells. PLoS ONE 7:e52181. doi: 10.1371/journal.pone.0052181

Vaughan, J., Donaldson, C., Bittencourt, J., Perrin, M. H., Lewis, K., Sutton, S., et al. (1995). Urocortin, a mammalian neuropeptide related to fish urotensin I and to corticotropin-releasing factor. Nature 378, 287-292. doi: 10.1038/ $378287 \mathrm{a} 0$

Vaughan, J. M., Donaldson, C. J., Fischer, W. H., Perrin, M. H., Rivier, J. E., Sawchenko, P. E., et al. (2013). Posttranslational processing of human and mouse urocortin 2: characterization and bioactivity of gene products. Endocrinology 154, 1553-1564. doi: 10.1210/en.2012-2011

Venihaki, M., Sakihara, S., Subramanian, S., Dikkes, P., Weninger, S. C., Liapakis, G., et al. (2004). Urocortin III, a brain neuropeptide of the corticotropinreleasing hormone family: modulation by stress and attenuation of some anxiety-like behaviours. J. Neuroendocrinol. 16, 411-422. doi: 10.1111/j.13652826.2004.01170.x

Vetter, D. E., Li, C., Zhao, L., Contarino, A., Liberman, M. C., Smith, G. W., et al. (2002). Urocortin-deficient mice show hearing impairment and increased anxiety-like behavior. Nat. Genet. 31, 363-369. doi: 10.1038/ng914

Wang, L., Basa, N. R., Shaikh, A., Luckey, A., Heber, D., St-Pierre, D. H., et al. (2006). LPS inhibits fasted plasma ghrelin levels in rats: role of IL-1 and PGs and functional implications. Am. J. Physiol. Gastrointest. Liver Physiol. 291, G611-G620. doi: 10.1152/ajpgi.00533.2005

Wang, L., Goebel-Stengel, M., Stengel, A., Wu, S. V., Ohning, G., and Taché, Y. (2011a). Comparison of CRF-immunoreactive neurons distribution in mouse and rat brains and selective induction of Fos in rat hypothalamic CRF neurons by abdominal surgery. Brain Res. 1415, 34-46. doi: 10.1016/j.brainres.2011.07.024

Wang, L., Martinez, V., Rivier, J. E., and Taché, Y. (2001). Peripheral urocortin inhibits gastric emptying and food intake in mice: differential role of CRF receptor 2. Am. J. Physiol. Regul. Integr. Comp. Physiol. 281, R1401-R1410.

Wang, L., Martinez, V., Vale, W., and Taché, Y. (2000). Fos induction in selective hypothalamic neuroendocrine and medullary nuclei by intravenous injection of urocortin and corticotropin-releasing factor in rats. Brain Res. 855, 47-57. doi: 10.1016/S0006-8993(99)02200-3

Wang, L., Stengel, A., Goebel, M., Martinez, V., Gourcerol, G., Rivier, J., et al. (2011b). Peripheral activation of corticotropin-releasing factor receptor 2 inhibits food intake and alters meal structures in mice. Peptides 32, 51-59. doi: 10.1016/j.peptides.2010.10.017

Weisinger, R. S., Blair-West, J. R., Burns, P., Denton, D. A., McKinley, M. J., Purcell, B., et al. (2000). The inhibitory effect of hormones associated with stress on Na appetite of sheep. Proc. Natl. Acad. Sci. U.S.A. 97, 2922-2927. doi: 10.1073/pnas.040577997

Weitemier, A. Z., and Ryabinin, A. E. (2006). Urocortin 1 in the dorsal raphe regulates food and fluid consumption, but not ethanol preference in C57BL/6J mice. Neuroscience 137, 1439-1445. doi: 10.1016/j.neuroscience. 2005.10.021

Wiltshire, S., Hattersley, A. T., Hitman, G. A., Walker, M., Levy, J. C., Sampson, M., et al. (2001). A genomewide scan for loci predisposing to type 2 diabetes in a U.K. population (the Diabetes UK Warren 2 Repository): analysis of 573 pedigrees provides independent replication of a susceptibility locus on chromosome 1q. Am. J. Hum. Genet. 69, 553-569. doi: 10.1086/323249

Wu, S. V., Yuan, P. Q., Lai, J., Wong, K., Chen, M. C., Ohning, G. V., et al. (2011). Activation of Type $1 \mathrm{CRH}$ receptor isoforms induces serotonin release from human carcinoid BON-1N cells: an enterochromaffin cell model. Endocrinology 152, 126-137. doi: 10.1210/en.2010-0997

Wu, S. V., Yuan, P. Q., Wang, L., Peng, Y. L., Chen, C. Y., and Taché, Y. (2007). Identification and characterization of multiple corticotropin-releasing factor type 2 receptor isoforms in the rat esophagus. Endocrinology 148, 1675-1687. doi: 10.1210/en.2006-0565

Wu, X., Cooper, R. S., Borecki, I., Hanis, C., Bray, M., Lewis, C. E., et al. (2002). A combined analysis of genomewide linkage scans for body mass index from the National Heart, Lung, and Blood Institute Family Blood Pressure Program. Am. J. Hum. Genet. 70, 1247-1256. doi: 10.1086/340362 
Wypior, G., Jeschke, U., Kurpisz, M., and Szekeres-Bartho, J. (2011). Expression of $\mathrm{CRH}, \mathrm{CRH}$-related peptide and $\mathrm{CRH}$ receptor in the ovary and potential CRH signalling pathways. J. Reprod. Immunol. 90, 67-73. doi: 10.1016/j.jri.2011.04.009

Yakabi, K., Noguchi, M., Ohno, S., Ro, S., Onouchi, T., Ochiai, M., et al. (2011). Urocortin 1 reduces food intake and ghrelin secretion via $\operatorname{CRF}(2)$ receptors. Am. J. Physiol. Endocrinol. Metab. 301, E72-E82. doi: 10.1152/ajpendo. 00695.2010

Yuan, P. Q., Million, M., Wu, S. V., Rivier, J., and Taché, Y. (2007). Peripheral corticotropin releasing factor (CRF) and a novel CRF1 receptor agonist, stressin 1-A activate CRF1 receptor expressing cholinergic and nitrergic myenteric neurons selectively in the colon of conscious rats. Neurogastroenterol. Motil. 19, 923-936. doi: 10.1111/j.1365-2982.2007.00978.x

Yuan, P. Q., Wu, S. V., Elliott, J., Anton, P. A., Chatzaki, E., Million, M., et al. (2012a). Expression of corticotropin releasing factor receptor type 1 (CRF1) in the human gastrointestinal tract and upregulation in the colonic mucosa in patients with ulcerative colitis. Peptides. 38, 62-69. doi: 10.1016/j.peptides.2012.07.028

Yuan, P. Q., Wu, S. V., and Taché, Y. (2012b). Urocortins and CRF type 2 receptor isoforms expression in the rat stomach are regulated by endotoxin: role in the modulation of delayed gastric emptying. Am. J. Physiol. Gastrointest. Liver Physiol. 303, G20-G31. doi: 10.1152/ajpgi.00547.2011

Yuan, P. Q., Wu, S. V., Wang, L., and Taché, Y. (2010). Corticotropin releasing factor in the rat colon: expression, localization and upregulation by endotoxin. Peptides 31, 322-331. doi: 10.1016/j.peptides.2009.11.012

Zmijewski, M. A., and Slominski, A. T. (2010). Emerging role of alternative splicing of CRF1 receptor in CRF signaling. Acta Biochim. Pol. 57, 1-13.
Zorrilla, E. P., Reinhardt, L. E., Valdez, G. R., Inoue, K., Rivier, J. E., Vale, W. W., et al. (2004). Human urocortin 2, a corticotropin-releasing factor (CRF)2 agonist, and ovine CRF, a CRF1 agonist, differentially alter feeding and motor activity. J. Pharmacol. Exp. Ther. 310, 1027-1034. doi: 10.1124/jpet. 104.068676

Zorrilla, E. P., Taché, Y., and Koob, G. F. (2003). Nibbling at CRF receptor control of feeding and gastrocolonic motility. Trends Pharmacol. Sci. 24, 421-427. doi: 10.1016/S0165-6147(03)00177-9

Conflict of Interest Statement: The authors declare that the research was conducted in the absence of any commercial or financial relationships that could be construed as a potential conflict of interest.

Received: 13 December 2013; paper pending published: 28 January 2014; accepted: 26 February 2014; published online: 18 March 2014.

Citation: Stengel A and Taché Y (2014) CRF and urocortin peptides as modulators of energy balance and feeding behavior during stress. Front. Neurosci. 8:52. doi: 10.3389/ fnins.2014.00052

This article was submitted to Neuroendocrine Science, a section of the journal Frontiers in Neuroscience.

Copyright (c) 2014 Stengel and Taché. This is an open-access article distributed under the terms of the Creative Commons Attribution License (CC BY).

The use, distribution or reproduction in other forums is permitted, provided the original author(s) or licensor are credited and that the original publication in this journal is cited, in accordance with accepted academic practice. No use, distribution or reproduction is permitted which does not comply with these terms. 